\title{
Platelet reactivity pattern in a patient with multiple pharmacogenetic factors of reduced clopidogrel efficiency
}

\author{
Jure Samardžić*, \\ Nada Božina, \\ Boško Skorić, \\ Miroslav Krpan, \\ Marijan Pašalić, \\ Lana Ganoci, \\ Mate Petričević, \\ Davor Miličić
}

Univesity of Zagreb School of Medicine, University Hos pital Centre Zagreb, Zagreb, Croatia

\begin{abstract}
KEYWORDS: pharmacogenetics, clopidogrel, acute coronary syndrome, platelet reactivity. CITATION: Cardiol Croat. 2015;10(9-10):206. | DOI: http://dx.doi.org/10.15836/ccar.2015.206
\end{abstract}

*ADDRESS FOR CORRESPONDENCE: Jure Samardžić, Klinički bolnički centar Zagreb, Kišpatićeva 12, HR-10000 Zagreb, Croatia / Phone: +385-1-2367466 / E-mail: jure.samardzic@gmail.com

ORCID: Jure Samardžic, http://orcid.org/0000-0002-9346-6402 • Nada Božina, http://orcid.org/0000-0001-6016-1699 Boško Skorić, http://orcid.org/0000-0007-5979-2346 • Miroslav Krpan, http://orcid.org/0000-0002-0639-953X Marijan Pašalić, http://orcid.org/0000-0002-3197-2190 • Lana Ganoci, http://orcid.org/0000-0003-3898-4554 Mate Petričević, http://orcid.org/0000-0002-2083-7751 • Davor Miličić, http://orcid.org/0000-0001-9101-1570

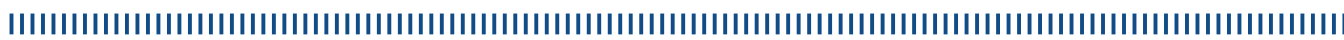

INTRODUCTION: Single nucleotide polymorphism of genes involved in clopidogrel metabolism may modulate platelet reactivity (PR) on clopidogrel and clinical outcome. Certain multidrug resistance gene 1 (MDR1) and CYP2C19 gene variants have been shown to impact clopidogrel pharmacodynamic effect by changing its absorption and biotransformation, respectively. Herein, we report PR pattern during 12 months of clopidogrel treatment in a patient with acute coronary syndrome (ACS) and multiple pharmacogenetic variations contributing to reduced clopidogrel effect. ${ }^{1-3}$

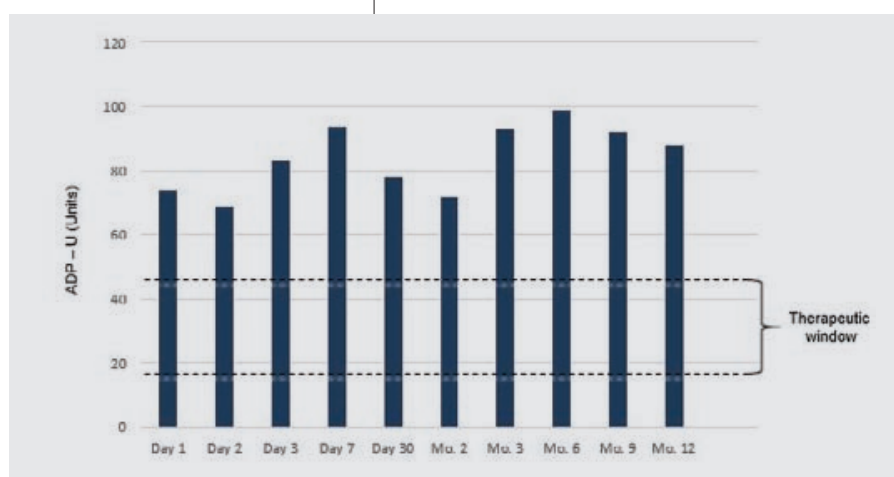

FIGURE 1. Platelet reactivity pattern during 12-month follow up.

PATIENTS AND METHODS: We performed post hoc pharmacogenetic analysis in our previously published randomized controlled trial which evaluated the effect of serial clopidogrel dose adjustment based on continuous platelet function testing (PFT) in ACS patients treated with PCI and with initially determined high ontreatment platelet reactivity on clopidogrel. Eighty-five patients were genotyped for G2677T/A and C3435T variants of MDR1 and CYP2C19. Only one patient was identified as homozygote for all three variants associated with decreased clopidogrel effect (CYP2C19*2,3435T and 2677T). The patient was assigned to control group and received standard clopidogrel dose.

PATIENT PRESENTATION: Fifty-four year old male, ethnic Roma (BMI $34 \mathrm{~kg} / \mathrm{m}^{2}$ ) with a past history of dyslipidemia and previous myocardial infarction was enrolled in the study with ustable angina as index event. Throughout 12 months follow up PR level was above cut-off value for HTPR set at 46U (Figure 1). Mean PR was 84.2U (min-max; 69-99U).

CONCLUSION: Routine pharmacogenetic testing in patients undergoing PCI is currently not recommended. Higher prevalence of CYP2C19*2 and 3435T alleles has been reported in Roma population compared to European Caucasians. ${ }^{3,4}$ Use of pharmacogenetic testing, PFT and administration of newer P2Y12 blockers such as ticagrelor and prasugrel should be considered to reduce ischemic risk in these patients.

RECEIVED:

August 27, 2015 ACCEPTED:

September 17, 2015

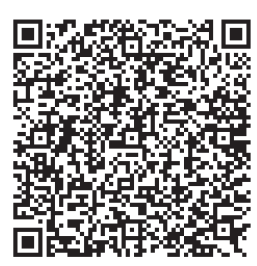

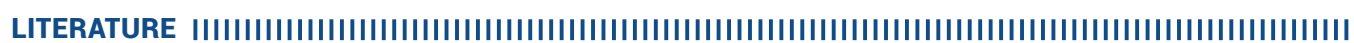

1. Mega JL, Close SL, Wiviott SD, Shen L, Walker JR, Simon T, et al. Genetic variants in ABCB1 and CYP2C19 and cardiovascular outcomes after treatment with clopidogrel andprasugrel in the TRITON-TIMI 38 trial: a pharmacogenetic analysis. Lancet. 2010;376(9749):1312-9. DOI: http://dx.doi.org/10.1016/S0140-6736(10)61273-1

2. Samardzic J, Krpan M, Skoric B, Pasalic M, Petricevic M, Milicic D. Serial clopidogrel dose adjustment after platelet function testing improves outcome of acute coronary syndrome patients undergoing percutaneous coronary intervention with high on-treatment platelet reactivity. J Thromb Thrombolysis. 2014;38(4):459-69. DOI: http://dx.doi.org/10.1007/s11239-014-1087-0

3. Sipeky C, Weber A, Szabo M, Melegh BI, Janicsek I, Tarlos G, et al. High prevalence of CYP2C19*2 allele in Roma samples: study on Roma and Hungarian population samples with review of the literature. Mol Biol Rep. 2013;40(8):4727-35. DOI: http://dx.doi.org/10.1007/s11033-013-2569-4

4. Sipeky C, Csongei V, Jaromi L, Safrany E, Maasz A, Takacs I, et al. Genetic variability and haplotype profile of MDR1 (ABCB1) in Roma and Hungarian population samples with a review of the literature. Drug Metab Pharmacokinet. 2011;26(2):206-15.

DOI: http://dx.doi.org/10.2133/dmpk.DMPK-10-SC-068 $\square$ Cardiologia Croatica 2015;10(9-10):206. 